\title{
Is childhood-onset Type I diabetes a wealth-related disease? An ecological analysis of European incidence rates
}

\author{
C. C. Patterson ${ }^{1}$, G. Dahlquist ${ }^{2}$, G. Soltész ${ }^{3}$, A. Green ${ }^{4}$ on behalf of the EURODIAB ACE Study Group* $^{*}$ \\ ${ }^{1}$ Department of Epidemiology and Public Health, Queen's University Belfast, Northern Ireland \\ ${ }^{2}$ Department of Clinical Science, Paediatrics University of Umeå, Sweden \\ ${ }^{3}$ Department of Paediatrics, University of Pećs, Hungary \\ ${ }^{4}$ Department of Epidemiology and Social Medicine, University of Aarhus, Denmark
}

\section{Abstract}

Aims/hypothesis. To describe the epidemiology of childhood-onset Type I (insulin-dependent) diabetes mellitus in Europe, the EURODIAB collaborative group established prospective, geographically-defined registers of children diagnosed under 15 years of age. A total of 16362 cases were registered by 44 centres during the period 1989-1994. The registers cover a population of approximately 28 million children with most European countries represented.

Methods. In most centres a primary and a secondary source of ascertainment were used so that the completeness of registration could be assessed by the capture-recapture method. Ecological correlation and regression analyses were used to study the relationship between incidence and various environmental, health and economic indicators.

Results. The standardised average annual incidence rate during the period 1989-94 ranged from 3.2 cases per 100000 person-years in the Former Yugoslavian
Republic of Macedonia to 40.2 cases per 100000 person-years in Finland. Indicators of national prosperity such as infant mortality $(r=-0.64)$ and gross domestic product $(r=0.58)$ were most strongly and significantly correlated with incidence rate and previously-reported associations with milk consumption $(r=0.58)$, coffee consumption $(r=0.51)$ and latitude $(r=0.40)$ were also observed.

Conclusion/interpretation. The wide variation in childhood Type I diabetes incidence rates within Europe could be partially explained by indicators of national prosperity. These indicators could reflect differences in environmental risk factors such as nutrition or lifestyle that are important in determining a country's incidence rate. [Diabetologia (2001) 44 [Suppl 3]: B 9-B16]

Keywords Type I diabetes mellitus, epidemiology, geographical variation, incidence, risk factors, ecological analysis, gross domestic product.
The low concordance rates of Type I (insulin-dependent) diabetes in monozygotic twin pairs [1-3], and the continuing increase in the incidence of Type I diabetes in many European countries in recent years confirms the importance of environmental factors as causes of this disease [4-7]. Useful clues about these environmental factors can be obtained

Corresponding author: Dr C. C. Patterson, Department of Epidemiology \& Public Health, The Queen's University of Belfast, Royal Victoria Hospital, Grosvenor Road, Belfast BT12 6BJ, UK

*see Acknowledgements by studying geographical variation in incidence rates in relation to the characteristics of the countries involved. Such ecological analyses should be undertaken with high-quality incidence data obtained from population-based registers adhering to a standard protocol. We have previously reported such data for the years 1989-90 from 26 registries in the EURODIAB Study Group and have established the existence of a wide range of incidence rates within Europe [8]. The network has since expanded to include 44 registries, with most European countries and Israel being represented. Incidence data in the 6-year period, 1989-94, are examined in this paper. 
We explored the wide geographic variation in incidence rates using ecological analysis. The strikingly higher incidence in Finland compared to ethnicallysimilar sub-populations in Estonia [9] as well as the apparent decrease in Type I diabetes in the war years in Germany [10] could reflect wealth-related risk factors. Therefore we studied geographical variability in relation to estimates of national prosperity. We also analysed a selection of indicators dictated mainly by existing environmental hypotheses. Coffee consumption, milk consumption and early breast-feeding have been the subject of previous ecological analyses and have also been studied at the individual level [11-15]. Climatological factors and population density have received rather less attention [16, 17]. A North-South gradient within Europe has long been hypothesised and prompted consideration of both latitude and longitude [18].

\section{Subjects and methods}

The establishment of the EURODIAB collaborative group of childhood diabetes registers has been described previously [8, 19]. In 1988 prospective registers of new subjects with Type I (insulin-dependent) diabetes mellitus among children under 15 years of age were established in 26 geographically-defined centres in Europe and Israel. Other centres, including many from the countries of Central and Eastern Europe, have since joined the group and the current membership of 44 centres includes most European countries.

In the majority of centres, both a primary and a secondary source of ascertainment were used to allow the completeness of registration be assessed. Primary sources were usually based on hospital records or on notifications by paediatricians and family doctors. Secondary sources varied depending on local circumstances but included social insurance schemes, diabetes associations and prescription data.

Subjects with Type I diabetes were identified on the basis of a clinician's diagnosis and the need for daily insulin injections. The date of onset was taken as the date of the first injection. Information on the date of birth, gender, sources of ascertainment (primary and/or secondary), date of clinical diagnosis and date of first insulin injection was submitted in anonymous form to a co-ordinating office in Odense, Denmark, for data processing.

Annual estimates of the resident population in each centre's area were obtained and were used as denominators in the calculation of incidence rates. Standardisation for age and gender was achieved using the direct method, the standard population comprising equal numbers in each of six subgroups defind by age-group (0-4, 5-9 and 10-14 years) and gender. All analyses were performed on the standardised rates.

For the ecological analysis, 34 geographical units were derived from the 44 centres by grouping together centres in the same country, unless they were situated in different land masses. Therefore Sardinia, Sicily, Madeira and Northern Ireland were each treated as separate centres distinct from their mainland counterparts.

For the ecological indicators the most appropriate figure for each centre (or group of centres) has been used but data for the nation as a whole has been substituted if no more specific information was available (e.g. Italian data have been used for Sardinia and Sicily). For centres from the former Czechoslovakia and Yugoslavia, figures relating to the original countries have been used when necessary. Coffee consumption data for 1990/91 (bags per 1000 head of population) were obtained from the International Coffee Organisation [20] and liquid milk consumption data for 1991 (or subsequent years if 1991 data were unavailable) from the International Dairy Federation [21]. Breast feeding rates were obtained by averaging the results of national surveys since 1980, which are recorded in the World Health Organisation Global Data Bank [22], unless there was a more relevant regional survey. When no national data was available regional surveys were substituted and if necessary the most recent pre-1980 survey was used. Lack of standardisation concerning the definition of breastfeeding duration meant that figures for breast-feeding only could be used. Cartographic data (latitude as ${ }^{\circ} \mathrm{N}$ and longitude as ${ }^{\circ} \mathrm{E}$ of the Greenwich meridian) and climatological data (rainfall, sunshine hours and temperature averages for up to 30 years) were also considered [23]. Population density figures (children under 15 years per $\mathrm{km}^{2}$ ) were derived from population data and estimates of study area provided by each centre. Health indicators (infant mortality and life expectancy) were estimates prepared in 1994 by the United Nations Population Division, obtained from the World Health Statistics Annual [24]. Gross domestic product per head of population for 1994, defined as the value of all goods and services produced within a country (measured on a purchasing power parity basis in US\$), was obtained from the World Health Organisation's Human Development Report [25]. The ecological data are presented in the Appendix.

Initial assessment of the ecological associations between the standardised incidence rates and characteristics of the various centres was obtained using simple (unweighted) Pearson's product-moment correlation coefficients. Both the standardised incidence rate and those indicators whose distribution was heavily skewed (infant mortality, gross domestic product, coffee consumption, milk consumption, population density and rainfall) were logarithmically transformed before analysis. Regression analyses were then performed with the logarithm of the rate as the dependent variable and indicators as independent variables. Only one independent variable was included at a time. Weights were defined by an iterative method to be intermediate between an unweighted analysis and an analysis with weights derived from the sampling variation of the standardised rates [26]. The analysis was performed using the GLIM package [27].

\section{Results}

Information summarizing all 44 of the participating centres, including the geographical coverage, the number of cases, the age-standardised and sex-standardised annual incidence rate and the estimated completeness of ascertainment, has already been published [19]. The standardised rates varied from 3.2 cases per 100000 person-years in the Former Yugoslavian Republic of Macedonia to 40.2 cases per 100000 in two regions of Finland. Incidence rates were highest in northern and north-western Europe and low in central, southern and eastern Europe, although Sardinia was a notable exception. In most centres, estimates of the completeness of ascertainment exceeded $95 \%$. 
Table 1. Incidence rates during 1989-94 for 34 EURODIAB ACE centre groupings

\begin{tabular}{|c|c|c|c|}
\hline Country & $\begin{array}{l}\text { Number of cases } \\
\text { in the period }\end{array}$ & $\begin{array}{l}\text { Average population } \\
\text { under } 15 \text { years } \\
\text { (thousands) }\end{array}$ & $\begin{array}{l}\text { Standardised incidence rate } \\
\text { (95\%-Confidence limits) } \\
\text { per } 100000 \text { person-years }\end{array}$ \\
\hline Austria & 753 & 1373.2 & $9.1(8.5,9.8)$ \\
\hline Bulgaria (two centres) & 521 & 1034.9 & $8.2(7.5,8.9)$ \\
\hline Croatia & 83 & 209.0 & $6.8(5.3,8.3)$ \\
\hline Czech Republic & 1144 & 2095.2 & $8.9(8.3,9.4)$ \\
\hline Finland & 425 & 175.4 & $40.2(36.4,44.1)$ \\
\hline France & 837 & 1662.6 & $8.3(7.8,8.9)$ \\
\hline Germany (two centres) & 1212 & 2050.3 & $11.5(10.8,12.1)$ \\
\hline Greece (two centres) & 382 & 686.7 & $8.9(8.0,9.8)$ \\
\hline Hungary & 822 & 1511.1 & $8.9(8.2,9.5)$ \\
\hline Iceland & 52 & 64.5 & $13.5(9.8,17.2)$ \\
\hline Lithuania & 368 & 834.3 & $7.4(6.6,8.1)$ \\
\hline Luxembourg & 49 & 68.2 & $12.1(8.7,15.5)$ \\
\hline Macedonia, Former Yugoslav Republic of & 93 & 486.9 & $3.2(2.5,3.8)$ \\
\hline Netherlands & 421 & 545.3 & $13.0(11.8,14.3)$ \\
\hline Norway & 491 & 393.0 & $21.2(19.3,23.1)$ \\
\hline Poland (four centres) & 1201 & 3618.4 & $6.1(5.8,6.5)$ \\
\hline Portugal (two mainland centres) & 76 & 82.6 & $15.0(11.6,18.4)$ \\
\hline Portugal - Madeira & 24 & 57.5 & $6.9(4.1,9.6)$ \\
\hline Romania & 138 & 449.5 & $5.0(4.1,5.8)$ \\
\hline Slovakia & 656 & 1290.4 & $8.4(7.7,9.0)$ \\
\hline Slovenia & 186 & 394.7 & $7.6(6.5,8.7)$ \\
\hline Spain & 839 & 1054.4 & $12.3(11.4,13.1)$ \\
\hline
\end{tabular}

For the ecological analyses, incidence results were pooled across centres from the same country (Bulgaria, Germany, Greece, mainland Italy, Poland, mainland Portugal and mainland United Kingdom) giving a total of 34 units for analysis (Table 1).

Preliminary analyses suggested that standardised incidence rate was most strongly associated with low infant mortality rate, high gross domestic product, high liquid milk and coffee consumption, long life expectancy and northern latitude (Table 2). The climatological variables showed very weak associations with incidence.

The iterative regression analysis identified the same group of six indicators as statistically significantly associated with incidence rate $(p<0.05)$. In general the results were much closer to those obtained by unweighted regression than by weighted regression, reflecting the fact that the greater part of the unexplained variation in rates between centres was not attributable to sampling variation in the rates. The fitted linear relationships between incidence (logarithmically transformed) and four of these indicators are depicted in Figures 1-4. The other two indicators, infant mortality rate and life expectancy, have been omitted because of their very high correlations with gross domestic product $(r=-0.88$ and 0.89 , respectively).

\section{Discussion}

The indicators of national prosperity that we found to be associated with incidence are most likely surrogates for other, still not identified, risk factors. The relevance of environmental influences early in life has been stressed and although the exact nature of these exposures is not yet clear, increased perinatal infections or a rapid growth rate in early life could be contributory factors [28-33]. Improving standards of hygiene, low rates of infection in infancy and low exposure to peer social contact in early life could also be relevant because they could interfere with the normal development of the immune system thus increasing the risk of autoimmune diseases such as childhood di- 


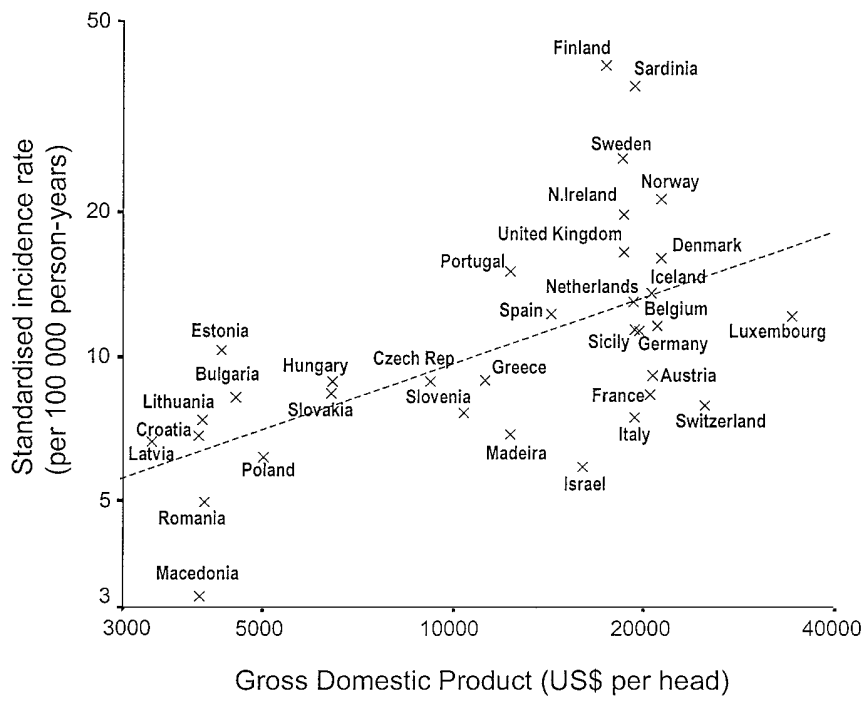

Fig. 1. Ecological association between childhood Type I diabetes incidence rates during 1989-94 and gross domestic product in 1994 measured on a purchasing power parity basis (US\$ per head)

abetes [34-38]. It is interesting to note that the ecological association with national prosperity is consistent with three of four small-area analyses in the United Kingdom [17, 39-41] that reported lower childhood diabetes rates in more materially-deprived areas.

Our analysis confirms that a relationship between incidence and latitude is present within Europe but we found only weak associations between incidence and climatological variables suggesting that they are not responsible for the north-south incidence gradient. A possible alternative explanation is that this gradient reflects an important source of genetic variation within Europe possibly attributable to historic patterns of migration in a north-westerly direction across Europe of Neolithic farmers from the Middle East and their partial admixture with local huntergatherer populations [42].

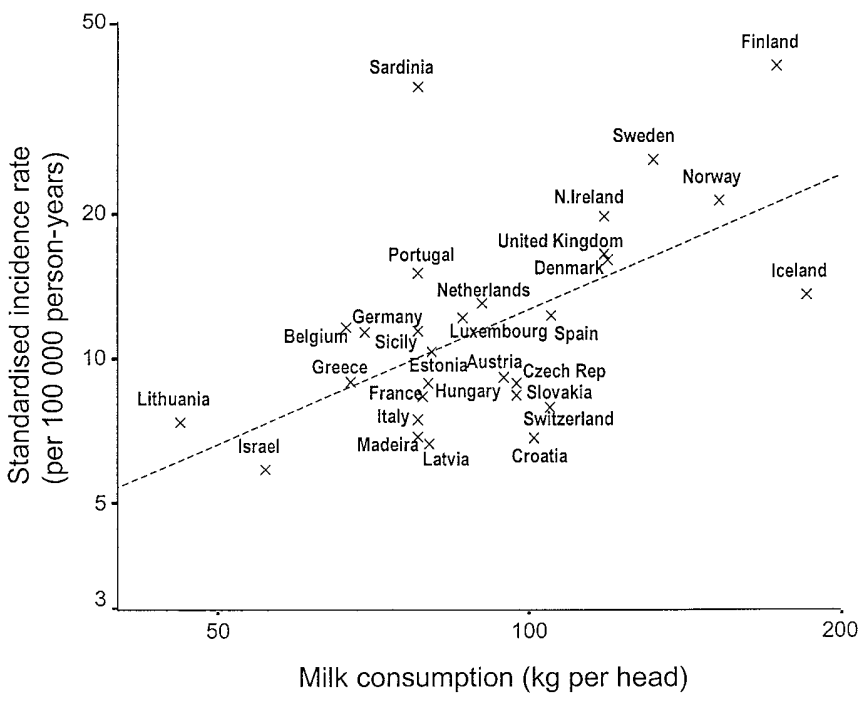

Fig. 2. Ecological association between childhood Type I diabetes incidence rates during 1989-94 and national liquid milk consumption ( $\mathrm{kg}$ per head)

Caution is recommended in interpreting ecological analyses as they can sometimes be misleading; associations observed at country level need not necessarily hold at individual level. Unfortunately the information required to explore this issue is not readily available. Our results raise the possibility that the previously reported associations between childhood incidence rate and population coffee and milk consumption could be attributable to confounding by other factors such as national prosperity or its correlates. It would have been easy to extend our regression model to include both coffee and milk consumption and indicators of national prosperity as predictor variables in order to investigate such confounding by using analyses similar to those employed to investigate confounding at the individual level. However, it has been shown that model misspecification and measurement error can have serious and unpredictable

Table 2. Correlation coefficients between indicators and standardised incidence rate ${ }^{\mathrm{a}}$ in 34 EURODIAB ACE centre groupings

\begin{tabular}{|c|c|c|c|}
\hline Indicator & $n$ & $\begin{array}{l}\text { Pearson correlation } \\
\text { coefficient, } r\end{array}$ & $p$ \\
\hline Infant mortality rate per $1000^{\mathrm{a}}$ & 34 & -0.64 & $<0.001$ \\
\hline Gross domestic product (US\$ per head)a & 34 & 0.58 & $<0.001$ \\
\hline Coffee consumption (bags per 1000 head) ${ }^{a}$ & 31 & 0.51 & 0.003 \\
\hline Life expectancy (years) & 34 & 0.50 & 0.003 \\
\hline Latitude $\left({ }^{\circ} \mathrm{N}\right)$ & 34 & 0.40 & 0.02 \\
\hline Any breast feeding (\%) & 29 & -0.21 & 0.28 \\
\hline Sunshine (hr) & 33 & -0.18 & 0.32 \\
\hline Rainfall $(\mathrm{mm})^{\mathrm{a}}$ & 34 & -0.16 & 0.36 \\
\hline Temperature $\left({ }^{\circ} \mathrm{C}\right)$ & 34 & -0.03 & 0.89 \\
\hline
\end{tabular}

\footnotetext{
${ }^{\text {a }}$ logarithmic transformation used
} 


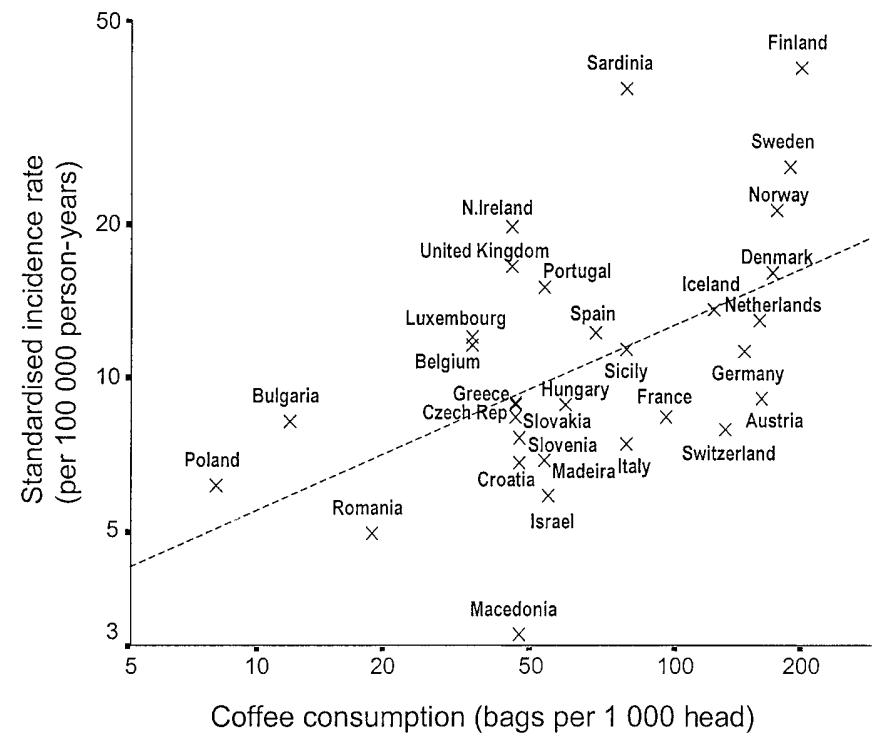

Fig. 3. Ecological association between childhood Type I diabetes incidence rates during 1989-94 and national coffee consumption (number of $60 \mathrm{~kg}$ bags per 1000 head)

consequences for the investigation of confounding in ecological analyses and could easily introduce further bias into estimates [43]. We therefore choose not to pursue this approach.

In conclusion, indicators of national prosperity could explain a significant portion of the large variability in childhood diabetes incidence rates across Europe. A wealthier lifestyle could influence normal growth and development and so increase the risk of childhood diabetes.

Acknowledgements. This study has been supported in part by the European Community Concerted Action Programme (Grants BMH1-CT92-0043 and BMH4-CT96-0577).

\section{The EURODIAB ACE Study Group}

Project Co-ordination: A. Green, Department of Epidemiology and Social Medicine, University of Aarhus; Denmark, G. Brutti, EURODIAB Co-ordinating Office, Odense University Hospital, Denmark.

Writing Committee: C.C. Patterson, Department of Epidemiology and Public Health, Queen's University Belfast, Northern Ireland. G. Dahlquist, Department of Clinical Science, Paediatrics, University of Umeå, Sweden; G. Soltész, Department of Paediarics, University of Pécs, Hungary; A. Green, Department of Epidemiology and Social Medicine, University of Aarhus, Denmark.

\section{Study Centres}

Austria: E. Schober, Department of Paediatrics, University of Vienna. Belgium: I. Weets, C. Vandevalle,

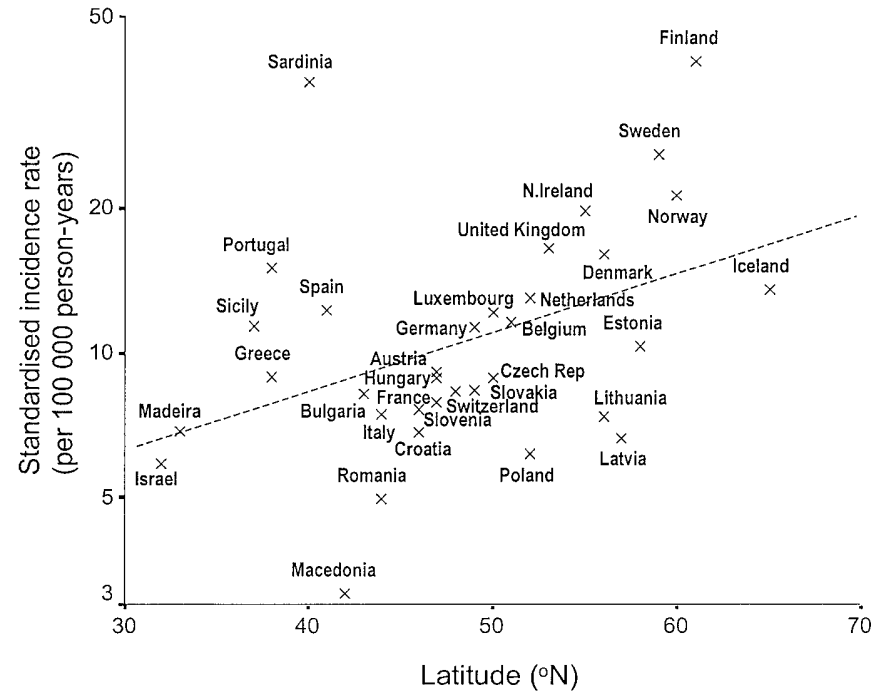

Fig. 4. Ecological association between childhood Type I diabetes incidence rates during 1989-94 and latitude

F. Gorus, M. Coeckelberghs, M. Du Caju, Belgian Diabetes Registry, Brussels. Bulgaria: V. Christov, Clinic of Endocrinology, University Alexandrov Hospital, Sofia; V. Tzaneva, V. Iotova, Department of Paediatrics, Clinic of Endocrinology Medical University, Varna. Croatia: G. Roglic, Vuk Vrhovac Institute, Zagreb. Czech Republic: J. Vavrinec, Second Clinic of Paediatrics, Charles University, Prague. Denmark: B.S. Olsen, A.J. Svendsen, J. Kreutzfeldt, E. Lund, Department of Paediatrics, KAS-Glostrup. Estonia: T. Poodar, Hospital of Endocrinology, Tartu. Finland: J. Tuomilehto, M. Karvonen, Diabetes \& Genetic Epidemiology Unit, National Public Health Institute, Helsinki. France: C. Levy-Marchal, P. Czernichow, J. Doutreix, INSERM U457, Department of Paediatric Endocrinolopy and Diabetes, Hospital Robert Debré, Paris. Germany: J. Rosenbauer, G. Giani, Diabetes Research Institute, Düsseldorf; A. Neu, Tübingen Paediatric Clinic, Eberhard-Karls-Universität. Greece: C. Bartsocas, K. Kassiou, C. Dacou-Voutetaki, A.C. Kafourou, A. Al-Qadreh, C. Karagianni, Department of Paediatrics, National University of Athens; N. Papazoglou, General Hospital Agios Pavlos, Thessaloniki. Hungary: G. Soltész, Department of Paediarics, University of Pécs. Iceland: A. V. Thorsson, Department of Paediatrics, University of Iceland, Reykjavik. Israel: Z. Laron, O. Gordon, Y. Albag, I. Shamis, Paediatric Endocrinology and Diabetes Research Unit, Petah Tikva. Italy: G. Chiumello, Third Paediatric Clinic, H San Raffaele Scientific Institute, Milano; P. Pozzilli, N. Visalli, L. Sebastiani, G. Marietti, R. Buzzetti, Biomedical University Campus, Rome; M. Songini, A. Casu, A. Marinaro, R. Ricciardi, M. A. Zedda, A. Milia, Department of Internal Medicine Hospital San Michele, Cagliari; F. Purrello, M. Arpi, G. Fichera, M. Mancuso, C. Lucenti, Department of Endocrinology, Garibaldi Hos- 
Appendix. Ecological data in 34 EURODIAB ACE centre groupings

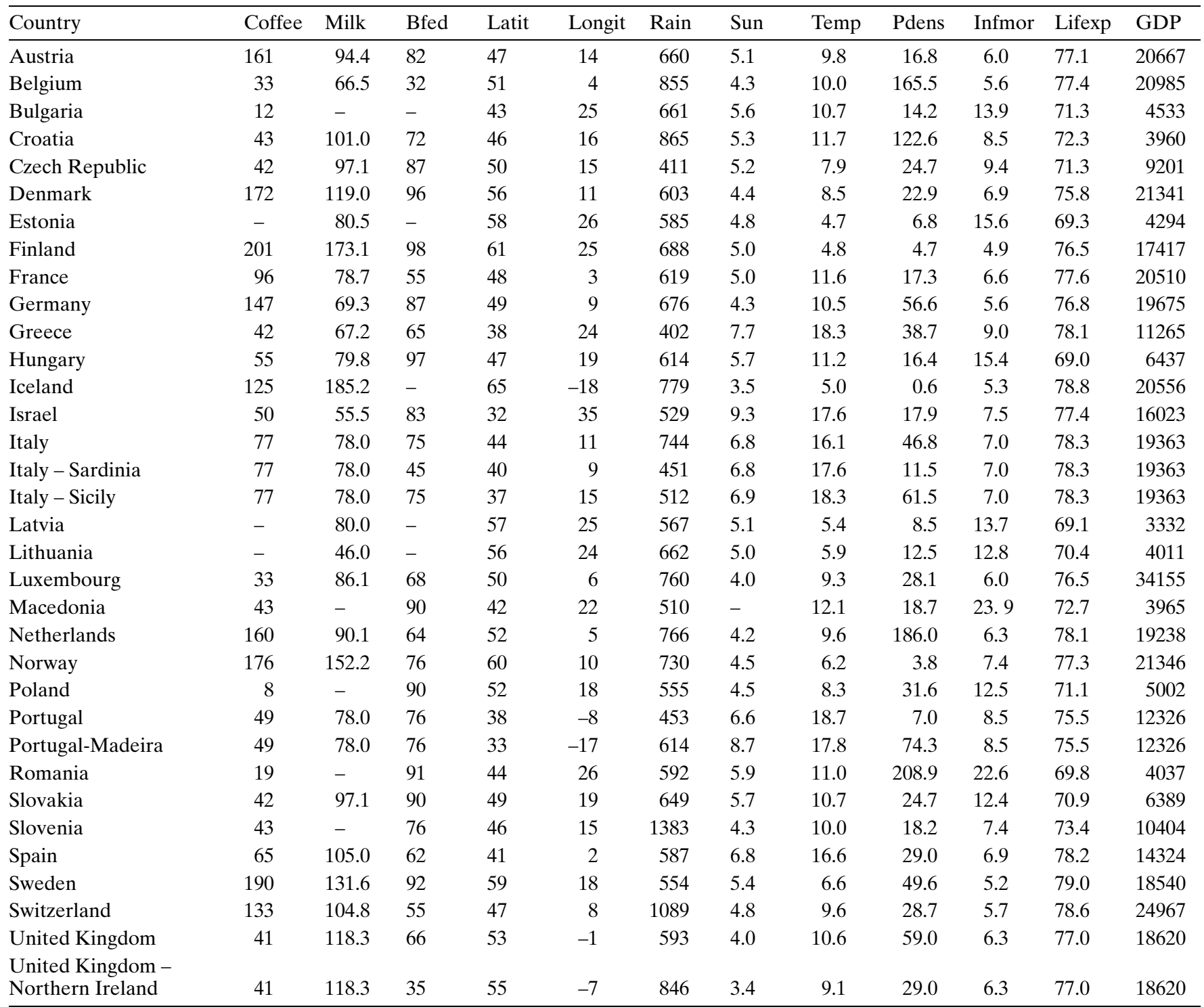

Notes for Appendix

\begin{tabular}{|c|c|c|}
\hline Indicator & Description & Source \\
\hline Coffee & $\begin{array}{l}\text { Coffee consumption in } 1990 / 91 \\
\text { ( } 60 \mathrm{~kg} \text { bags per } 1000 \text { head) }\end{array}$ & $\mathrm{ICO}$ \\
\hline Milk & $\begin{array}{l}\text { Liquid milk consumption in } 1991 \text { or later } \\
\text { (kg per head) }\end{array}$ & IDF \\
\hline Bfed & $\begin{array}{l}\text { Breast feeding ever (\%) from surveys con- } \\
\text { ducted since } 1980\end{array}$ & GDB \\
\hline Latit & Latitude (degrees $\mathrm{N}$ ) of major urban area & TAW \\
\hline Longit & $\begin{array}{l}\text { Longitude (degrees E) of major urban area } \\
\text { (negative denotes degrees W) }\end{array}$ & TAW \\
\hline Rain & Annual rainfall (mm) & WWG \\
\hline Sun & Average sunshine (hours per day) & WWG \\
\hline Temp & $\begin{array}{l}\text { Average of monthly min. and max. average } \\
\text { daily temperatures }\left({ }^{\circ} \mathrm{C}\right)\end{array}$ & WWG \\
\hline
\end{tabular}

\begin{tabular}{lll}
\hline Indicator & Description & Source \\
\hline Pdens & $\begin{array}{l}\text { Population density (under 15 year popula- } \\
\text { tion per km²) }\end{array}$ & ACE \\
Infm or & Infant mortality in 1995 (per 1000 livebirths) & WHS \\
Lifexp & Life expectancy in 1995 (both sexes) & WHS \\
GDP & $\begin{array}{l}\text { Gross Domestic Product in 1994 purchasing } \\
\text { power parity basis (US\$ per head) }\end{array}$ & HDR \\
\hline
\end{tabular}

Key to sources

ICO, International Coffee Organisation; IDF, International Dairy Federation Bulletin; GDB, Global Data Bank on breast feeding, World Health Organisation Nutrition Program; TAW, Times Atlas of the World; WWG, World Weather Guide; ACE, EURODIAB ACE co-ordinating centre; WHS, World Health Statistics Annual, World Health Organisation; HDR, Human Development Report, World Health Organisation 
pital, Catania. Latvia: G. Brigis, Public Health and Epidemiology, Latvian Academy of Medicine, Riga. Lithuania: B. Urbonaité, Institute of Endocrinology, Kaunas Medical Academy. Luxembourg: C. De Beaufort, Luxembourg Paediatric Clinic. Macedonia (Former Yugoslav Republic): M. Kocova, Pediatric Clinic, Medical Faculty, University of Skopje. Netherlands: M. Reeser, Juliana Children's Hospital, The Hague. Norway: G. Joner, Department of Community Health, Folkehelsa-Epidemiology, Oslo. Poland: D. Woznicka, Paediatrics, Endocrinology and Diabetes, University of Medical Sciences in Poznan; Z. Szybinski, Department of Endocrinology, Jagiellonian University, Krakow; P. Jarosz-Chobot, Department of Children's Endocrinology, Silesian School of Medicine, Katowice; I. Kinalska, Department of Endocrinology, University Hospital, Bialystok. Portugal: S. Abreu, Endocrinology Unit Funchal Hospital Centre, Madeira; C. Menezes, Department of Internal Medicine, Portalegre District Hospital; E. A. Pina, Department of Medicine, Faro District Hospital. Romania: C. Ionescu-Tirgoviste, Department of Nutrition and Metabolic Disease, University of Bucharest. Slovakia: D. Michalková, P. Hlava, M. Mikulecký, J. Črnay, First Paediatric Clinic, University Komensky, Bratislava. Slovenia: C. Krzisnik, T. Battelino, N. Bratina-Ursic, Endocrine, Diabetes and Metabolic Diseases, University Medical Centre, Ljubljana. Spain: A. Goday, Department of Endocrinology, Hospital del Mar, Barcelona. Sweden: G. Dahlquist, Department of Clinical Science, Paediatrics, University of Umeå. Switzerland: E. Schönle, University Paediatric Clinic Eleonoren-Stiftung, Childrens Hospital Zürich. United Kingdom: C. Patterson, R. Greenlees, D. Carson, D. Hadden, University Belfast; P. Bingley, Department of Medicine, Southmead Hospital, University of Bristol; N. Raymond, Department of Epidemiology and Public Health, University of Leicester; P. A. McKinney, H. J. Bodansky, C. Stephenson, Institute of Epidemiology and Health Services Research, University of Leeds.

\section{References}

1. Leslie RDG, Lo SSS, Hawa M et al. (1992) Lessons on the etiology of insulin-dependent diabetes from twin studies. In: Levy-Marchal C, Czernichow P (eds) Epidemiology and Etiology of Insulin-dependent Diabetes in the Young. Karger, Basle

2. Kaprio J, Tuomilehto J, Koskenvuo M et al. (1992) Concordance for Type I (insulin-dependent) and Type II (non-insulin dependent) diabetes mellitus in a population based cohort of twins in Finland. Diabetologia 35: 1060-1067

3. Kyvik KO, Green A, Beck-Neilsen H (1995) Concordance rates of insulin dependent diabetes mellitus: a population based study of young twins. BMJ 311: 913-917

4. Karvonen M, Tuomilehto J, Libman I, LaPorte R (1993) A review of the recent epidemiological data on the worldwide incidence of Type I (insulin-dependent) diabetes mellitus. Diabetologia 36: 883-892

5. Green A, Sjolie AK, Eshoj O (1997) The epidemiology of diabetes mellitus. In: Pickup JC, Williams G (eds) Textbook of Diabetes. Blackwell Science, Oxford

6. Onkamo P, Väänänen S, Karvonen M, Tuomilehto J (1999) Worldwide increase in incidence of Type I diabetes - the analysis of the data on published incidence trends. Diabetologia 42: 1395-1403

7. Rosenbauer J, Herzig P, von Kries R, Neu A, Giani G (1999) Temporal, seasonal, and geographical incidence patterns of Type I diabetes mellitus in children under 5 years of age in Germany. Diabetologia 42: 1055-1059

8. Green A, Gale EAM, Patterson CC for the EURODIAB ACE Study (1992) Incidence of childhood-onset insulindependent diabetes mellitus: the EURODIAB ACE Study. Lancet 339: 905-909

9. Tuomilehto J, Podar T, Reunanen A et al. (1991) Comparison of incidence of IDDM in childhood between Estonia and Finland, 1980-1988. Diabetes Care 14: 982-988

10. Dorner G, Thoelke H, Mohnike A, Schneider H (1985) High food supply in perinatal life appears to favour the development of insulin-treated diabetes mellitus (ITDM) in later life. Exp Clin Endocrinol Diabetes 85: 1-6

11. Tuomilehto J, Tuomilehto-Wolf E, Virtala E, LaPorte R (1990) Coffee consumption as trigger for insulin dependent diabetes in childhood. BMJ 300: 642-643

12. Dahl-Jorgensen K, Joner G, Hanssen KF (1991) Relationship between cows' milk consumption and incidence of IDDM in childhood. Diabetes Care 14: 1081-1083

13. Scott FW (1990) Cow milk and insulin-dependent diabetes mellitus: is there a relationship? Am J Clin Nutr 51: 489-491

14. Virtanen SM, Rasanen L, Aro A et al. (1994) Is children's or parents' coffee or tea consumption associated with the risk for Type I diabetes mellitus in children? Eur J Clin Nutr 48: 279-285

15. Gerstein HC (1994) Cow's milk exposure and type I diabetes mellitus. A critical overview of the clinical literature. Diabetes Care 17: 1713-1719

16. Dahlquist G, Mustonen L (1994) Childhood onset diabetes - time trends and climatological factors. Int J Epidemiol 23: 1234-1241

17. Patterson CC, Waugh NR (1992) Urban/rural and deprivational differences in incidence and clustering of childhood diabetes in Scotland. Int J Epidemiol 21: 108-117

18. Vaandrager GJ, Bruining GJ, Veenhof FJ, Drayer NM (1984) Incidence of childhood diabetes in The Netherlands: a decrease from north to south over north-western Europe? Diabetologia 27: 203-206

19. EURODIAB ACE Study Group (2000) Variation and trends in the incidence of childhood diabetes in Europe. Lancet 355: 873-876

20. International Coffee Organisation (1996) Coffee statistics no 4. International Coffee Organisation, London

21. International Dairy Foundation (1993) Consumption statistics for milk and milk products 1991 (Bulletin no 282), International Dairy Federation, Brussels

22. World Health Organisation Nutrition Unit (1990) Breastfeeding: prevalence and duration, Europe. World Health Organisation, Geneva

23. Pearce EA, Smith CG (1984) World Weather Guide. Hutchinson, London

24. World Health Organisation (1996) World Health Statistics Annual 1995. World Health Organisation, Geneva

25. World Health Organisation (1997) Human Development Report 1997. Oxford University Press, New York 
26. Pocock SJ, Cook, DG, Beresford SAA (1981) Regression of area mortality rates on explanatory variables: What weighting is appropriate? Appl Statist 30: 286-295

27. Francis B, Green M, Payne C (1993) The GLIM system release 4 manual. Clarendon Press, Oxford

28. Leslie RD, Elliott RB (1994) Early environmental events as a cause of IDDM. Evidence and implications. Diabetes 43: 843-850

29. Dahlquist GG (1997) Viruses and other perinatal exposures as initiating events for beta-cell destruction. Ann Med 29: 413-417

30. Dahlquist GG, Ivarsson S, Lindberg B, Forsgren M (1995) Maternal enteroviral infection during pregnancy as a risk factor for childhood IDDM. A population-based case-control study. Diabetes 44: 408-413

31. Hyöty H, Hiltunen M, Knip M et al. (1995) A prospective study of the role of Coxsackie B and other enterovirus infections in the pathogenesis of IDDM. Diabetes 44: 652-657

32. Blom L, Persson LA, Dahlquist G (1992) A high linear growth is associated with an increased risk of childhood diabetes mellitus. Diabetologia 35: 528-533

33. Johansson C, Samuelsson U, Ludvigsson J (1994) A high weight gain early in life is associated with an increased risk of Type I (insulin-dependent) diabetes mellitus. Diabetologia 7: 91-94

34. Kolb H, Elliott RB (1994) Increasing incidence of IDDM a consequence of improved hygiene? Diabetologia 37: 729-731
35. Gibbon C, Smith T, Egger P, Betts P, Phillips D (1997) Early infection and subsequent insulin dependent diabetes. Arch Dis Child 77: 384-385

36. McKinney PA, Okasha M, Parslow RC et al. (2000) Early social mixing and childhood diabetes: a case-control study in Yorkshire, UK. Diabet Med 17: 236-242

37. The EURODIAB Substudy 2 Study Group (2000) Infections and vaccinations as risk factors for childhood Type I (insulin-dependent) diabetes mellitus: a multicentre casecontrol Investigation. Diabetologia 43: 47-53

38. Rook GAW, Stanford JL (1998) Give us this day our daily germs. Immunol Today 19: 113-116

39. Crow YJ, Alberti KG, Parkin JM (1991) Insulin dependent diabetes in childhood and material deprivation in northern England. BMJ 303: 156-160

40. Patterson CC, Carson DJ, Hadden DR (1996) Epidemiology of childhood IDDM in Northern Ireland 1989-1994: Low incidence in areas with highest population density and most household crowding. Diabetologia 39: 1063-1069

41. Staines A, Bodansky HJ, McKinney PA et al. (1997) Small area variation in the incidence of childhood insulin-dependent diabetes mellitus in Yorkshire, UK: Links with overcrowding and population density. Int $\mathrm{J}$ Epidemiol 26: 1307-1313

42. Cavalli-Sforza LL, Piazza A (1993) Human genomic diversity in Europe: A summary of recent research and prospects for the future. Eur J Hum Genet 1: 3-18

43. Greenland S, Robins J (1994) Ecological studies - biases, misconceptions, and counterexamples. Am J Epidemiol 139: 747-760 